\title{
Selvagens pacíficos: as antinomias da civilização nos rituais sadomasoquistas
}

\author{
Peaceful wild: the antinomies of civilization at the \\ sadomasochist rituals
}

Marcelo Gonçalves Rodrigues*

Recebido em: 10/2015

Aprovado em: 11/2015

\begin{abstract}
Resumo: Este artigotem o objetivo de refletir, por meio da Teoria Crítica da Sociedade,sobre as condições objetivas sociais incisivas à determinação deespetáculos de violência, lutas de MMA, mercantilizados na indústria cultural sob a marca UFC. Pretende-se discutir os prejuízos à formação crítica advindos dos estratagemas mercadológicos, violentos em sua base de produção, que autorizam a partirda predisposição à educação pela dureza, o consumo de objetos performáticos e legitimadores da frieza burguesa. Além disso, apontar que a relação entre sociedade, cultura, educação e violência concreta, é de intensa contradição. Sendo assim,refletir sobre as consequências da miséria material maligna à subjetividade pode ser uma alternativa de retirar de circuito a violência de destruiçãoimediata do outro. $O$ artigoserá, portanto, umaanáliseconceitualapoiadanas bases da primeirageração de pensadores da TeoriaCrítica, sem a intenção de esgotar o assunto.

Palavras chave: Indústria Cultural, Violência, Frieza Burguesa, MMA, UFC
\end{abstract}

\begin{abstract}
This articlehas the objectiveto reflect through the Critical Theory of Society, about the social conditions incisive to determination of spectacleof violence, MMA fights, commodified in the cultural industry under the UFC mark. It intends to discussas the damages to critical formation come from the marketing ploys, violents at the production base, that
\end{abstract}

\footnotetext{
"Mestrando em Educação Escolar pela Universidade Estadual Paulista "Júlio de Mesquita Filho" UNESP - Araraquara.

Email-marcelo_gonc@yahoo.com.br

Problemata: R. Intern. Fil. v.6, n. 3(2015), p 378-403 ISSN 2236-8612 doi:HTTP://dx.doi.org/10.7443/problemata.v6i3.26000
} 
authorize from the propensity education through harshness, the consumption of show business of bourgeois coolness. Moreover, point that the relation between society, culture, education and violence, is of intense contradiction. Therefore,reflect about the consequences of material misery malignant to subjectivity, it is important to understand the violence of immediate destruction of other. The article will be, therefore, a conceptual analysis supported on the basis of the first generation of thinkers of Critical Theory not intended to exhaust the subject.

Keywords: Cultural Industry, Violence, Bourgeois Coolness, $M M A, U F C$

\section{Introdução}

O objetivo deste trabalho é discutir alguns pontos entre sociedade, educação e eventos regressivos chancelados via indústria cultural. $O$ intuito é o de esboçar uma crítica que possibilite compreender a profusão derituais sadomasoquistas destrutivos numa época de espetacularização em que a violência também é mercadoria.O foco de análise não será diretivo aos 'esportes' de combate ou em suas tipificações pitorescas. Não será delineada uma retomada históricada modalidade. Será, sim, efetuada uma crítica às condições objetivas sociais operantesà determinação da violência em espetáculos de excitação, como lutas. Para isso, é decisivo alongar a interpretação às múltiplas variantes cotidianas que regulam e pautam a nossa existência na cultura e no capital.

A seguir, serão explicados alguns apontamentos básicos à assimilaçãodo temapara se articular uma reflexão sobre os desdobramentos conceituais do trabalho. Como a temática é abrangente, é necessário, para fins de apresentação, não se imiscuir de pontuar o norte da crítica em alguns movimentos, são eles: compreender que a violência calcada numa racionalidade tecnocientífica regulada e reforçada na cultura a partir da estrutura social contraditória de mercado,libera sintomas autoflageladores de objetificação do corpo, inclusive, no lazer administrado. Entender que há um duplo caráter dos modelos de esportes na indústria cultural negociados como sinônimo de saúde e bem-estar, por outro lado, com fins catárticos em práticas regressivas espetacularizadas, dentre as quais, destaca-se a luta de MMA - MixedMartialArts, comercializada via UFC-UltimateFighting Championship.

Problemata: R. Intern. Fil. v.6, n. 3(2015), p 378-403 ISSN 2236-8612 
A dupla face esportiva é o sintoma da relação de estranheza e sacrifício que temos com o corpo advindo em certa medida da ordem social econômica regida na cultura pelo viés dilacerante do consumo e do mercado. Este ao fomentar a grande violência social que subjaz no funcionamento do modus operandi do princípio de troca capitalista, revela-nos a violência na base produtivista do social. Atrelado a este agressivo processo de aceleramento de mercadorias está o encurtamento da dimensão temporal. Um tempo livrepreenchido por um lazer célere e disparador de adrenalina e choque, na contramão dos meios para se vislumbrar uma formaçãoque resista à apropriação de estéticas sacrificiais de endurecimento.Nesse sentido, haja vista, a hierarquia social estratificadora, propulsora de personalidades sadomasoquistas, o esclarecimento acerca da construção intrapsíquica do ressentido, incapaz de reconhecer semelhanças e diferençasno outro, é essencial para se ampliar o entendimentoa respeitoda abertura de espaços a objetos culturais agressivos.Esses elementos, em grande medida, escapam à observação da sociedade que em seu ancoramento pouca ênfase credita às nuances de sua própria contradição.Possibilitar o espaço de discussão da ausência de uma educação que reflita os processos históricos sociais e suas mediações com o sujeito é fundamental por: demonstrar a carência de debates e diálogos maciços no campo ético que desembrulhem as antinomias da civilização, e a impossibilidade de concretização da subjetividade autônoma na objetividade material de vida atual.

É relevante esclarecer que, fomentar a crítica e colocá-la em movimento de percepção em facedas determinações contraditórias do social, significa, antes de tudo, revelar que não se pode se eximirenquanto sujeito constituído e representante dessa ambiguidade denunciada. Dessa forma, é sine qua non compreender-se inscrito, e, reprodutor ativo das problemáticas do social concreto de existência.Por tudo isso, entende-se que direcionar a análise unicamente ao evento de MMA seria perder de vista os bastidores e caminhos que levam ao local da luta.O trabalho será uma análise conceitual apoiada na perspectiva da Teoria Crítica nas bases cunhadas pela sua primeira geração de pensadores. Ressalte-se que essa distensão reflexiva é substancial à dimensão do objeto e de suas mínimas vertentes. Em vista disso, faz-se preponderante essa consideração, sem evidentemente a pretensão de completude. 


\section{Um repensar do progresso congelado}

Para início, podemos questionar o que ou quais condições, especificamente, conduzem amaioria àimpressão de que a violência se presentifica cada vez mais na sociedade. Primeiro, uma ilusão que repousa num encantamento do passado remoto, reconciliado, não paradoxal e regularmente pragmático. Segundo que essa concepção faz parte da ideia de história que os sujeitos possuem. Um movimento positivista, linear e homogêneo. Em outros termos, um pensamento a-histórico e ideológico por justificar a barbárie do presente sem conexão com o passado inamistoso.De acordo com Benjamin (1994), se assombrar com fatos do presente revela um sujeito vítima de uma normatividade de história que torna aquiloque era para ser "estado de exceção" - a sucessão de tronos pela dominação social - a regra absoluta. É uma concepção insustentável que necessita ser repensada, pois "A história é objeto de uma construção cujo lugar não é o tempo homogêneo e vazio, masum tempo saturado de "agoras" (BENJAMIN, 1994, p.229).Isto atesta que há no curso da história uma repetição, o mesmo em eterno retorno. Com base neste autor e em suas reflexões áureas acerca da dimensão temporal da história, nos é demonstrado nointerior de sua crítica que não há um monumento de cultura que não o seja de barbárie, bem como seu próprio processo transmissivo. Uma sucessão de temporalidade igual que sintetiza o seguinte: pobreza de experiência é barbárie. É um começar novamente e com muito pouco. Uma pobreza alastrada em nosso âmago que nos legou a construção das ruínas do patrimônio da humanidade o qual "muitas vezes tivemos que empenhá-lo por um centésimo de seu valor, para receber em troca a moeda miúda do "atual". (BENJAMIN, 1986, p.198).

Essas denúncias têmrelação estreita com o franco declínio da crítica, da reflexão ea pauperização de uma função primordial: a memória. Como argumenta Zuin (2011) ao lembrar Nietzsche, quanto mais fraca a memória coletiva dos povos, tanto mais sacrificial, duro e violento serão os rituais praticados para internalização da consciência e das leis do grupo. Memória e dor têm relações intrínsecas. A angústia é um processo queexiste via lembranças desagradáveis que 
novamente ressurgem como denominado por Türcke (2010). Portanto, angústia e medo ditam o tom da memória. E o medo, conforme denomina este pensador, foi o único mecanismo de sobrevivência nos primórdios do mundo animal. Porém, trata-se de um intenso fundamento em contradição. A destruição da memória viva de tempos passados nas sociedades pré-patriarcais se deu por meio da aplicação de penas terríveis nos homens tal como verificado en passant na dialética do esclarecimento por Adorno e Horkheimer (1985). Mas amalgamado a esses fatos históricos de práticas regressivas, ocorre, em contradição, a ascensão da cultura. Pois se o progresso é irrefreável é irrefreável a sua regressãojá que "todo o progresso da civilização tem renovado, ao mesmo tempo, a dominação e a perspectiva de seu abrandamento" (ADORNO e HORKHEIMER, 1985, p.44).

O pensamento ideológico professa uma falsa reconciliação homogênea e uma história sem história, o que, forja, portanto, a percepção sobre a origem da opressão e dominação que perfila nas relações sociais. Se o homem de neanderthal aniquilava o seu companheiro a golpes de sílex, o contemporâneo extermina com maior "eficiência"- o outro, ou com tiros de fuzis, ou com o próprio progresso científico material a partir da restrição e exclusão de seus benefícios. Embora nosso corpo não fabrique veneno para se defender e ou atacar, possui, o poder de criação, e com esta, produzir indivíduos mais fracos e controláveis socialmente, o bárbaro obrigado a girar sem sair do lugar, sem olhar para a esquerda e nem para direita.

Como lembrado, mecanismos de controle remontam a priscas eras e permanecem atuais por mais que se neguem as incongruências materiais e humanas de sua constituição.Ora, sentimentos arcaicos trabalhados no curso da história da natureza como dor, medo e angústia, fundamentais à sobrevivência e à adaptação ao mercado estão em evidência para reforçar essa questão.Por isso nas palavras de Türcke (2010), "Apenas sobreviventes podem ter angústia; ela já é um modelo de sucesso" (p.155).Adaptação a um sistema doentio de exploração constitui o que podemos chamar de frieza burguesa. Tanto que, há, simultaneamente, a afirmativa da inflação do mal e aapatia geralperante suas ocorrênciascomo se estas não nos dissessem respeito.Se atentarmos o olhar à eficiência técnica, perceberemos que esta ofertou aos determinantes sociais da

Problemata: R. Intern. Fil. v.6, n. 3(2015), p 378-403 ISSN 2236-8612 
violência meios mais sofisticados de açãoque permite sua propagação mais rápida, e, ao mesmo tempo, silenciosa. Isso quer dizer que a violência, que assola socialmente todas as classes, muito embora em diferentes graus, passa, muitas vezes, despercebida, não obstante sua alta reprodução. Mas, não se pode esquecer que uma das razões dessa propulsão refreada é a frialdade que potencializa os indivíduos principalmente para que se acotovelem por um lugar de sobrevida no capitalismo.

A vida no capitalismo tardio é um contínuo rito de iniciação. Todos têm que mostrar que se identificam integralmente com o poder de quem não cessam de receber pancadas. Eis aí, aliás, o princípio do jazz, a síncope, que ao mesmo tempo zomba do tropeção e erige-o em norma. A voz de eunuco do croonera cantar no rádio, o galã bonitão que, ao cortejar a herdeira, cai dentro da piscina vestido de smoking, são modelos para as pessoas que devem se transformar naquilo que o sistema, triturando-as, força-as a ser. (ADORNO e HORKHEIMER, 1985, p.127).

Nessa dinâmica fagocitante os sujeitos se veem forçados a se ajustar sob o preço de sua própria aniquilação. São eliminadas de si as possibilidades de uma crítica dialética a respeito dasmediações históricos sociais. Isso implica nainexistência de reflexão acerca da correlação entre as injustiças econômicas, a carência de acesso à apropriação cultural, bem como na incidência repetitiva em torno de seus acontecimentos violentos que se tornam fugidios.

Essa condição desnuda uma situação comum a boa parte das pessoas imersas na loucura do cotidiano: a sensação historicamente enraizada, na esfera individual, de impotência política e financeira para transformar minimamente a objetividade material de existência. Segundo Adorno (1995b) efetuar o paralelismo entre o tédio, o cinza objetivo e a apatia política traz o sentimento completamente verossímil das massas de que pouco podem mudar em sua existência em virtude da pífia margem de participação política a que lhe é reservada pela sociedade. Se a participação é diminuta, como resistir ao status quo e ou transformá-lo?

Se o resultado final chega transformado aos sujeitos e sem entendimento da constituição do objeto que se lhe apresenta, é impossível desvelar alguma transformação consciente em torno 
do que lhes acomete. Por isso, silêncio, apatia e medo generalizado têm raízes na não apreensão das mediações.Em vistada existência sacrificante dos sujeitos aprofundados na superficialidade das exigências de adequação,é uma tarefa árdua obrigá-los a efetuar movimentos de resistências sem perceberem que o mundo pelo qual lutam, contrariamente, não lhes dá sentido e nem garantias.Temos um impasse. É premente a autonomia para realocação da subjetividade do sujeito na materialidade que danifica sua existência. Porém, a heteronomia é o impeditivo à autonomia porque é a forma integrante à cultura pela qual todos estão regidos de alguma forma desde o nascer. Portanto, num processo intenso de contradição "Todos podem ser como a sociedade todo-poderosa, todos podem se tornar felizes, desde que se entreguem de corpo e alma, desde que renunciem à pretensão de felicidade". (ADORNO e HORKHEIMER, 1985, p.127).

Conforme Gruschka (2014) é preciso entender que os homens não são em essência frios, porém, o que subjaz na constituição da frieza aos homens são as próprias reproduçõesmateriais a que são impingidos de aceitar se quiserem viver minimamente. A formação burguesa condiciona os sujeitos a serem indiferentes primeiramente contra si e em seguida entre si. Permitir-se ser usado e espoliado sob o jugo dos detentores dos meios de produção é a condição única para muitos conseguirem sobreviver onde há ilusão de vida. A maneira de encontrar respaldo e sobrevivência perante a própria aniquilação, demonstra uma capacidade genuína das novas gerações, como alertado por Adorno e Horkheimer (1985). Pois,

Eles são aptos para qualquer trabalho porque o processo de trabalho não os liga a nenhum em particular. Isso lembra o caráter tristemente amoldável do soldado que retorna de uma guerra que não lhe dizia respeito, ou do trabalhador que vive de biscates e acaba entrando em ligas e organizações paramilitares. A liquidação do trágico confirma a eliminação do indivíduo.(ADORNO e HORKHEIMER, 1985, p.127).

Os problemas sociais de ordem material corroboram para despencar a qualidade moral das relações dos sujeitos que ficam de alguma forma desafetados. É necessário ailusão e chistes para se resistir às agruras do cotidiano. Benjamin (1994) elucubra que os sonhos são a compensação da tristeza e do desânimo do

Problemata: R. Intern. Fil. v.6, n. 3(2015), p 378-403 ISSN 2236-8612 
dia ao possibilitar a existência de uma vida simples e grandiosa impossível de ser concretizada durante o dia, por simples falta de forças. O camundongo Mickey é a representação desses sonhos, cuja existência demonstra o movimento milagroso e mágico no qual técnica, conforto, primitivismo e natureza são consubstanciados por inteiro. Mas à apatia do indivíduo no cotidiano cinzento sem perspectivas se contrapõe a aceleração ininterrupta dos meios de produção e uma compressão da experiência temporal. Embora, haja considerável desenvolvimento tecnocientífico e ampla objetividade material, não há menos pobreza e nem maiorliberdade, há o deslocamento dos determinantes fundamentais de base econômica para $\mathrm{o}$ reforço da racionalidade operacional do sistema capitalista. Ora, com excesso de administração no âmbito da vida carente de experiências, não se tem a humanização da humanidade, uma vez que, ao capitalismo o ser ontológico é o próprio capital. O humano serve apenas de aporte para a sacramentação de seus usurpadores modelos de realização.

Mesmo com o poderio dos sistemas de reengenhariae considerável quantidade de terras, será que ainda não é possível erradicar a fome que, segundo Kepple (2014), abarca um contingente de 805 milhões depessoas no mundo? Temos os mecanismosinformatizadoso suficiente para se trabalhar menos e produzir comida em larga escala de forma que ninguém morresse por desnutrição ou demales menores. A produção $a d$ infinitumérestrita ao consumo,eem seus pressupostos ocorre a venda no e do tempo livre. Portanto,essa objetificação pela qual passam os sujeitos consumidores necessita de tempo. Isso aponta para um dos pontos cruciais para se pensar ouso temporal no lazer:situar sua fragmentação a partir dos ideários burgueses.

\section{Tempo livre e recreação racional}

Adorno (1995b) afirma porque é normativo às pessoas separar o tempo de trabalho do livre: a folga deve ser utilizadacomo economia de energias físicas e psíquicas com vistas aum desempenho mais vivo e concentrado no trabalho, replicando as próprias formas de trabalho, a folga passa a não existir. Harvey (2000) estrutura algumas elaborações a respeito do tempo de giro do capital e da produção global de 
mercadorias. As produções de necessidades são tanto sofisticadas quanto bestializadas na simplificação das necessidades. Estas dependem dos produtores que visam dinheiro, assim:

O produtor capitalista tem cada vez mais "o papel de alcoviteiro" entre os consumidores e seu sentido de necessidade, excitando neles "apetites mórbidos, à espreita de cada uma de suas fraquezas - tudo isso para que possa exigir o numerário pelo seu serviço de amor". O prazer, o lazer, a sedução e a vida erótica são trazidos para o âmbito do poder do dinheiro e da produção de mercadorias. (HARVEY, 2000, p.99).

A vivência temporal fica comprimida e acelerada na intensificação da produção e aquisição de mercadorias. O lazer técnico espetacular ao ser integralizado por meio do passatempo dispendioso aos trabalhadores intensifica-se aopromover a identificação com a lógica dominante. Debord(2004) a respeito de um tempo destinado em ocupações alienadas, num lazer administrado, nos diz:

O tempo pseudocíclico é o disfarce consumível do tempo - mercadoria da produção. Contém os caracteres essenciais de unidades homogêneas intercambiáveis e de supressão da dimensão qualitativa. Mas, como ele é o subproduto desse tempo destinado ao atraso da vida cotidiana concreta - e à manutenção desse atraso -, deve estar carregado de pseudovalorizações e aparecer numa sequência de momentos falsamente individualizados. (DEBORD, 2004, p.104).

A ciência se possibilita(r) o prolongamento da vida é para amplificar o tempo de trabalho e de retroalimentação do capital, uma sobrevivência fetichizada. O tempo presente é regulado pelo tempo passado. Para atenuar a sensação de morbidez a indústria cultural administra o lazer tanto com picadas óticas viciantes quanto com rituais sadomasoquistas. $\mathrm{O}$ movimento vai de um contato nulo virtualizado em aplicativos microeletrônicosao contato corporal extremado em atividades de alta tensão física. As relações dos sujeitossão pautadas pela dinâmica do capital, e convertidas em propriedades, cujo dono, é a reificação que osassujeitam.Há a desigualdade que torna a igualdade uma realização impossível no sistema de substituição.

Problemata: R. Intern. Fil. v.6, n. 3(2015), p 378-403 ISSN 2236-8612 


\begin{abstract}
A teoria descreve muito bem o que ocorre com o tempo livre das pessoas sob aquelas condições, que Kant teria denominado situação de heteronomia e que, hoje, em alemão moderno, se costuma chamar de heterodeterminação; também o arrogante dito de Shopenhauer de que as pessoas são produtos fabris da natureza atinge, através de seu cinismo, algo daquilo que determina nas pessoas a totalidade do caráter de mercadoria. (ADORNO, 1995b, p.75-76).
\end{abstract}

Entretenimentos de altoestresse físico adentram ao lazer dada a condição de objetificação dos sujeitos administrados no equivalente universal de troca. Não à toa, técnica e esporte são afins na mesma medida em que são ambíguos (ADORNO, 1995a). Pois, o esporte pode proporcionar o fairplaye o respeito ao mais fraco, e dependendo da modalidade pode incitar à agressão e ao sadismo. Ao invés de reeducação dos sentidos, o esporte é falseado pela indústria como operador de autocontrole.

Controlar o corpo é discipliná-lo ao trabalho, éreduzi-lo à mera imitação de gestos mecânicos, uma propaganda de felicidade apática.Nessa direção o esporte possui o expediente que o identifica à violência da produção das mercadorias que tem o operário - mimese do atleta - nolimite de suas forças. Quando indústria esociedade reduzem o esporte somente à saúde, chancela-se um corpo operacionalizado, e a dureza à adaptação das exigências de performance de alto nível.E ao se vender o esporte de lutas como sublimação artística e, como oportunidade - por mais que esta seja em pontos isolados a realidade de uma minoria - para superar as dificuldades objetivas da existência, é torná-lo legitimador da frieza e violência que horroriza o cotidiano.

\title{
Ressentimento e educação pela dureza
}

A explanação teve o intento de discutir algumas notassobre a violência na racionalidade tecnocientífica. Rapidamente foram sintetizadaspequenas colocações sobre a administração do tempo livre e do esporte na sociedade hodierna empregados para revigoramento a partir do consumo de atividades excitativas - produtos de estética kitsch - o que perfila o pensar no embotamento. A seguir, será tratado o 
conceito de ressentimento, mecanismo eliciado no processo de semiformação heterônomo.Discussão preponderante à perspectiva crítica para o entendimento acercada frieza burguesa nas ações de desejo destrutivo.

Para elucidar essa questão,serão utilizados os contornos teoréticos de dois pensadores: Adorno com sua apropriação freudiana da psicanálise e Nietzsche. $\mathrm{O}$ propósito é, modestamente,percorrer como os dois filósofos representaram a interpretação desse movimento intrapsíquico reverberado, grosso modo, na identificação psicológica repulsiva com o objeto simbolizado como diferente, por isso, uma tentativa de expulsar de dentro de si por ser o núcleo de encontro a sua impotência e falta. Trata-se da apatia generalizada ante as particularidades do objeto.

Essa tensão de conceitos é plausível à apreensão dos efeitos e consequências de uma educação repressora do medo numa sociedade excitada por espetáculos de pavor e dos seus alongamentos imbricados no psiquismo dos sujeitos. $\mathrm{O}$ fenômeno de retroalimentação do ódio ou educação pela dureza, leva em conta características subjetivadas aderentes a esses formatos intrapsicológicos. Dentre os quais: o autoritarismo, a obediência e a sedimentação do preconceito.

Adorno (1995a) nos diálogos com Becker - educação contra a barbárie- discute sobre os atos ideológicos e demagógicos da sociedade ao criminalizar as manifestações de rua - reivindicação por melhorias no plano político social - de intervenção bárbara. Em oposto, o filósofo diz que essa ação ratifica a não nulidade da educação política e a possibilidade de as pessoas não se inclinarem à instrumentalização coisificada da ordem vigente.
A forma de que a ameaçadora barbárie se reveste atualmente é a de, em nome da autoridade, em nome de poderes estabelecidos, praticarem-se precisamente atos que anunciam, conforme sua própria configuração, a deformidade, o impulso destrutivo e a essência mutilada da maioria das pessoas. (ADORNO, 1995a, p.159).

Em nome dessas duas forças, os indivíduos se coagem destilando medo e ódio. Isso marca o caráter regressivo à primitiva violência, ao amedrontar boa parte das pessoas; seja com o pavor da eliminação e dos cortes econômicos 
empresariais, dos quais, ninguém está isento; seja pela ronda do fantasma da morte social iminente.

Se as possibilidades de transformação radical da esfera material se mostram impossíveis de objetivação própria por conta das contradições da própria sociedade e da cultura modelada em razão desta realidade apologética ao mercado e consumo, como se pensar a modificação da estrutura social e do modus psicológico de ações agressivas destrutivas?

Adorno (1995a) enfatiza a subjetividade paracombater os pressupostos ideológicos que fundam a cultura e o indivíduo nesses sintomas.Todavia se esse controle social com suas balizas refletidas na dogmática representatividade do capital conduz a objetificação sem objeto do próprio homem como provocar o movimento a contrapelo daquilo que está solidificado em grande profundidade cultural e social? O impasse ético sobre o que é o problema resultante da objetividade e o que é a sua solução via subjetividade, é, no momento, contraditoriamente a única possibilidade de se pensar a liberdade. Ao mesmo tempo, liberdade é impossível de se concretizar em virtude da apropriação pelos indivíduos da materialidade da vida real, contrária a sua realização, nos moldes atuais.

Em vista disso, para a mitigação social, nascem soluções frias a partir do discurso de tolerância: obrigação de amar e aceitar o outro. Essas mensagens em formato de slogan propagandístico são rijas tanto quanto os livros escolares de geopolítica que mostram a foto de crianças africanas cadavéricas, para as quais sequer é efetuada uma retrospecção histórica com intuito de esclarecer como e quem produz um mundo acessível a poucos. A ausência de pensamento perante essas imagéticas de choque é o de apenas intimidar um remorso sem conflito no sujeito que observa.Este, muito pouco pode fazer com a minguada força que lhe resta para rotineiramente competir com os mais próximos para sustentar seu tímido lugar no mercado. Sua frieza é a de não se identificar com o que é fraco, pois isso traria riscos consideráveis à permanência de seu falso semblante. E perdê-lo, ratifica sua invalidação social, sendo que, para muitos, essa exígua aparência é o todo que sobra dado o cerco ao ajuste social.Há uma dominação interna radicalizada pelo próprio sujeito, uma reconfiguração para se adaptar sob o jugo de uma autoconservação social que elimina a 
própria essência, substância viva do sujeito que seria o mais importante a ser conservado, conforme o trecho a seguir:

O domínio do homem sobre si mesmo, em que se funda o seu ser, é sempre a destruição virtual do sujeito a serviço do qual ele ocorre; pois a substância dominada, oprimida e dissolvida pela autoconservação, nada mais é senão o ser vivo, cujas funções configuram, elas tão somente, as atividades da autoconservação, por conseguinte exatamente aquilo que na verdade devia ser conservado. A antirrazão do capitalismo totalitário, cuja técnica de satisfazer necessidades, em sua forma objetualizada, determinada pela dominação, torna impossível a satisfação de necessidades e impele ao extermínio dos homens - essa antirrazão está desenvolvida de maneira prototípica no herói que se furta ao sacrifício sacrificando-se.(ADORNO e HORKHEIMER, 1985, p.54).

Por essa via - de dominação contra ameaças externas e internas - que não se trata de costurar de maneira simplista, taxativa e sem mediação as ocorrências de violência na sociedade com alternativas pré-digeridas como comumente ocorrem. Como os protótipos de cunho fundamentalista modulados em cartilhas de auto-ajuda e regras de comportamento charlatãs.São estes mecanismos supostamente apaziguadores que se sedimentam as soluções ideológicas e intensificam a barbárie que tanto se quer combater. A atenção ao campo subjetivado permite a introspecção de enxergar que a violência permanece presente em todos os âmbitos da dinâmica compulsiva da vida material, que exige agressividade $\mathrm{e}$ combatividade para ser enfrentada.Portanto, é fornecer subsídios ao sujeito de se reconhecer a presença da violência na formação da cultura, na história geral e pessoal.

Esse percurso de esclarecimento não necessariamente significa a libertação da ameaça de violência, e nem se responsabilizar individualmente por sua existência. Tampouco se locupletar de historicização e cruzar os braços crendo já ter justificado as ocorrências do problema. É, acima disso, não negá-la. Porém, reconhecê-la com crítica e resistência para que não seja passível de legitimidade e, sobretudo, estofo político para mascarar os contrassensos da ordem ética social. É romper com quaisquer instâncias ideológicas de reconciliação romântica entre civilização e natureza.E provocar a indagação de como 
encontrar um papel duradouro à cultura e educação com vistas a inverteros propósitos arcaicos de eliminação imediata do outro.

Resolver, portanto, problemas que exigem aprimoramento na senda da formação moral e educacional na qual emergem conflitos e incômodos entre os sujeitos, requer cautela. Numa sociedade historicamente segregacionista em todos os níveis, o incômodo com a simples presença da diferença é propiciada a partir do próprio mal-estar advindo dessa cultura.Porquanto, direcionar o conflito para a dureza e repressão compalavras, que vão desde a pieguice e aos gritos de ordem, forma o que Adorno (1995a) critica no modo frio de se resolver dilemas do campo formativo. Trata-se da ideologia que secreta barbárie e armazena o processo de repulsa psicológica.Daí a importância da educação não repressiva e autorreflexiva para eliminar lacunas que desemboquem o sujeito na paranóia neurótica como, os clichês, a mentalidade dos tickets que redundam na frieza, antiintelectualismo, e o produto final, a razão instrumental.

Não acredito que adianta muito apelar a valores eternos,
acerca dos quais justamente os responsáveis por tais
atos reagiriam com menosprezo; também não acredito
que o esclarecimento acerca das qualidades positivas
das minorias reprimidas seja de muita valia. É preciso
buscar as raízes nos perseguidores e não nas vítimas [...]
Torna-se necessário o que a esse respeito uma vez
denominei de inflexão em direção ao sujeito.
(ADORNO, 1995a, p.121).

Esse dilema moral é recorrente na indústria escolar na qual em seus circuitos ocorrem o uso da dominação. Primeiro porque se trata de um local de reprodução dos meios de dominação do capital. Segundo porque a educação é heterônoma e reproduz as antinomias da sociedade. Os acontecimentos de violência escolar poderiam ser pensados como meios de se trabalhar e destacar as diferenças constitutivas do humano. Porém, gira-se no inverso. Busca-se a igualdade abstrata num mundo em desigualdade concreta, romantizado aos alunos numa generalidade de falsa harmonia. Os conflitos desencadeados a partir dos apelidos jocosos, por exemplo, são dissolvidos e intensificados com ameaças punitivas.

Genericamente, a solução encontrada é semelhante ao próprio ato reprovado: usa-se de um procedimento instrumental de se apossar a partir da mostra de fraqueza do outro com o

Problemata: R. Intern. Fil. v.6, n. 3(2015), p 378-403 ISSN 2236-8612 
intuito de transformar suas dificuldades e sofrimentos em escárnio.Ao manipular e vilipendiar, objetifica-se o depositário para convergência da agressividade do algoz. Há uma absolutização e inflexibilidade impostas a objetos existentes e negação agressiva a seu modo particular. Não se pode experienciar e recusa-se de antemão o que lhe soa, simultaneamente, diferente e reconhecível.Há pontos de semelhança ignorados. $\mathrm{O}$ antissemita não suporta o judeu, mas o imita constantemente. $\mathrm{O}$ aluno imita fervorosamente o professor implicitamente odiado. Imitar o objeto de ódio traduz as cifras miméticas, o principium individuationis fisionômico é o caractere que de acordo com Adorno e Horkheimer (1985), inscreve no próprio rosto do indivíduo seu caráter particular.

Os campos de concentração, na Alemanha, explicitam não somente essa racionalidade instrumental que ancorou a paranóia persecutória nazista de extermínio das diferenças, todavia evidenciou o objeto primitivo de dominação do homem. A fragilidade do eu psíquico encabeçou a conivência de boa parte dos alemães ao terror. Juntar-se à ameaça para que esta não perceba sua presença como alvo, gera a massificação não na igualdade, contudo, na indiferença.Antes de se perseguir os verdugos expondo-os como dejetos perniciosos ou estandartizar as vítimas como endereços de comiseração, pureza e isentos de contradições, seria preciso refletir sobre a sociedade e o trabalho social que servem às rédeas do mercado agressivo eexcludente, a partir da crítica ao modelo de educação respaldado na competição e na severidade da força e disciplina.

Se a educação cujo fim primordial seria o de propiciar reflexão em torno das atitudes mais íntimas; gerar conhecimento,deslocamento de consciência, interpretação e incômodo com a realidade, ou: "trabalhar no sentido de superar representações infantis e infantilismos dos mais diferentes tipos" (ADORNO, 1995a, p.162); incita à formação debilitante de competidores ávidos pela melhor colocação, e replica o operacionalismo cru das relações de negócios, como evidenciar aos indivíduos suas possibilidades de humanidade se este está fundado no princípio de troca burguês? Em tese, para Adorno (1995a) é imprescindível que se reconheça os mecanismos que tornam as pessoas capazes de cometer atos bárbaros para que percam essa capacidade de ação. 
Para zelar a educação da primeira infância e possibilitar um clima intelectual, cultural e social para que Auschwitz não se repita (ADORNO, 1995a), é imperativo mudar a base violenta dos meios de produção e reprodução do capital. A manutenção incessante da reprodução de mercadorias se deve à sensualidade do capitalismo como produtor de desejos. O capitalreverbera a promiscuidade e a santidade a um só tempo de giro perceptual no consumidor que atende, unicamente, as demandas mercadológicas. A luta se restringe a objetos com obsolescência anunciada.Numa atmosfera social de pouco acesso ao que de melhor materialmente fora produzido pela humanidade, tem fundamento os indivíduos procurarem enterrar seus parcos bens igual ao gesto canino de preservação do alimento em caso de eventuais crises.

Esse métodocaótico de 'sobrevivência' não é exatamente idêntico ao bellum omnium contra omnes, entretanto,não é contraditório ao referido postulado hobbesiano. Para Adorno e Horkheimer (1985) a paranóia é o sintoma de sujeitos semiformados, algo comum nessa modernidade primitiva. $\mathrm{O}$ suspeitarjá é a ameaça em si da própria liberdade e da cultura, desse modo,"A tendência à falsa projeção é tão fatalmente inerente ao espírito que ela, esquema isolado da autoconservação, ameaça dominar tudo o que vai além dela: acultura" (p.161).O indivíduo semiformado projeta com maior volúpia, e, projeção em ato contínuo instaura a paranóia, melhor definida como a sombra do conhecimento. Assim, segundo Adorno (1995a) a psicanálise deveria ter importância à formação dos sujeitos para compreensão dos meandros de sua própria queda.

Esse problema da falsa projeção sintetizado como estereotipia do pensar - explica-nos que esse mecanismo consiste no deslocamento ao objeto dos impulsos dos sujeitos reprimidos socialmente. Em asserções freudianas o super eu violenta o eu, que em defesa, projeta no exterior os impulsos agressivos advindos do id que de tão forte, revela-se numa ameaça ao sujeito. Singelamente é como se o sujeito sentisse um roubo de sua felicidade, diminuição do seu espaço de gozar raptado por um intruso. Essa perda de espaço imaginário retrata a falta do sujeito. $\mathrm{O}$ super eu reenvia no processo de incômodo e perturbação a própria impotência do sujeito, a não resolução de sua fantasia castrada. $\mathrm{O}$ indivíduo se livra disso, no campo 
imaginário, na identificação com o agressor, e no real, na desculpa de legítima defesa. Imputa-se no outro o inexplicável vazio que o preenche.

A racionalização da defesa já é a desculpa para se fazer o que se deseja. Dessa feita,odesejo se funda no que o contraria, e esse contrário é a pedra angular que estrutura a insatisfação do próprio desejo. Quanto maior a volúpia dessa falta, tanto maior será a violência imaginária hospedeira nesse desejo. A fúria viril denota o risco potencializado em todo homem da ameaça de castração. Nessa angústia, o homem visualiza seu oponente como o agente responsável por incitar o desencadeamento dessa ameaça, logo, tem que ser destruído, por sê-lo um entrave ao desenvolvimento. Isso, no entanto, na esfera imaginária do psiquismo. No plano material, observa-se, nas políticas governistas em comunhão com o capital financeiro especulativo, a transformação dos locais a base de violência. 'Limpar' o território para promoção do "desenvolvimento" urbano social. Todosem atraso, no fim da fila, retardatários que sinalizem empecilho ao lucro e que espelham fraqueza e impotência social têm de ser extirpados. Os endereçados desse ódio são o mendigo, a população indígena, presidiários, os moradores da favela etc.

\begin{abstract}
Um esquema sempre confirmado na história das perseguições é o de que a violência contra os fracos se dirige principalmente contra os que são considerados socialmente fracos e ao mesmo tempo - seja isto verdade ou não- felizes. De uma perspectiva sociológica eu ousaria acrescentar que nossa sociedade, ao mesmo tempo em que se integra cada vez mais, gera tendências de desagregação. Essas tendências encontram-se bastante desenvolvidas logo abaixo da superfície da vida civilizada e ordenada. A pressão do geral dominante sobre tudo o que é particular, os homens individualmente e as instituições singulares, tem uma tendência a destroçar o particular e individual juntamente com seu potencial de resistência. (ADORNO, 1995a, p. 122).
\end{abstract}

A violência social urbana é reduzida à ação isolada dos indivíduos desfavorecidos. Não são efetuadas relações entre o ato e a dimensão histórica social, tampouco os reflexos advindos dos interesses vis das esferas política e econômica. Aos praticantes da violência ou simples suspeitos resta alei de Lynch

Problemata: R. Intern. Fil. v.6, n. 3(2015), p 378-403 ISSN 2236-8612 
sem possibilidade de defesa. Parte disso provém do incentivo espetacular da mídia, que em sua grosseria, ao não explicar os determinantes objetivos de causa, deflagram as massas à coletivização do ódio. Um sujeito educado de determinada maneira a comprometer sua própria inserção aos padrões normativos representados na sociedade, não pode ser responsabilizado isoladamente pelas ações consequentes de seus sintomas produzidos pelo mesmo objeto que lhe aponta a sentença de culpa sem direito à defesa. A sociedade mesmo com seus significativos avanços não oferece minimamente tratamento, apenas leis de ajuste para proliferar os 'desencontrados'.

A exposição dos atos violentos é radicalizado para ressoar que a sua causa localiza-se no sujeito por meio de uma diagnose de transtornos psiquiátricos. Por outro lado, repercute a produção do princípio do medo constitutivo em que ordens de sensações são introjetadas via experiência estética no psiquismo dos sujeitos de tal forma que estes certificam à objetividade material insegurança e horror sem a constatação de uma ameaça iminente. Não é preciso a ocorrência de um mal, apenas o rumor de sua possibilidade ventilada pelos aparelhos de Estado: polícia, religião, e mídia. $\mathrm{O}$ risco de malear e inflamar sentimentos de medo, não é apenas aquele que já ocorre em algumas partes do Brasil como o linchamento ou prisão de inocentes, mas de tornar rotineira práticas deverdadeiros assassinatos rituais, como os pogromsda Rússia czarista e da Alemanha nazista, a barbáriede que nos falam Adorno e Horkheimer (1985).

Veremos, agora, resumidamente como, para Nietzsche, ocorrea formação do ressentimento. Em sua obra - Genealogia da moral: Uma polêmica - Nietzsche (1998) tratou do princípio fundante do ressentimento. $\mathrm{O}$ filósofo propiciou uma escavação nos âmagos psicológicos para emergir à luz as causas raízes dos sentimentos de ressentimento e o queperfila nessas emoções calcinadas. Os sujeitos interditados de exaurir qualquer reação ou manifestação diante de uma situação de contexto particular são feridos em seu núcleo singular, em sua constituição. Nesta ação osujeito fica impedido de extroverter sua afirmação e passa a introverter os resíduos ao encontro dos grotões obscurecidos da impulsividade de destruição e rancor. 
Os seres privados daquilo que lhes poderia abrir a fronteira de aspiração à civilidade ou acesso a processos de desenvolvimento que fundamentaria uma experiência formativa elaborada, passam a recusar de antemão toda e qualquer situação de experenciar um objeto diferente. Essa recusa é o ato que atenua o sofrimento do ressentido, é a vingança imaginária que efetua a reparação de machucados não cicatrizados. Essa ação de negar, segundo Nietzsche (1998), é na verdade a reação a uma ação caótica à psique do sujeito que fora privado e esquecido em algum ponto de sua história de vida. A inversão do olhar ao extroverter no lugar de introverter para si o estabelecimento de valores, é próprio do ressentimento, é o requerer da moral escrava para nascer, um mundo oposto e exterior, para então poder agir. (NIETZSCHE, 1998).Ao ressentido fica a ambiguidade: ele crê promover procedimentos de cura a sua lacuna emotiva, por outro, essa própria ação é reação e agrava as feridas a ponto de calejá-lo, daí o endurecimento e frialdade.

\footnotetext{
Quando o modo de valoração nobre se equivoca e peca contra a realidade, isso ocorre com relação à esfera que não lhe é familiar, que ele inclusive se recusa bruscamente a conhecer; por vezes não reconhece a esfera por ele desprezada, a do homem comum, do povo baixo; por outro lado, considere-se que o afeto do desprezo, do olhar de cima para baixo, do olhar superiormente, a supor que falseie a imagem do desprezado, em todo caso estará muito longe do falseamento com que o ódio entranhado, a vingança do impotente, atacará- in effigie, naturalmente- o seu adversário (NIETZSCHE, 1998, p.29).
}

Conforme Nietzsche (1998) a exigência que a força não se revele como força ou desejo de dominação, vontade de vitória e triunfos, subjugação e sede de inimigos é no sentido inverso obrigar que a fraqueza apresente-se como força. Isso é oportuno para se pensar que o arrependimento em torno da agressão ao outro é encorajada pelas possíveis perdas e cerceamento que o agressor venha a sofrer do que pelo ato em si e seus prejuízos à vida da vítima. Não é a efetivação emocional de um conflito interno de retrospecção de sua atitude, uma neurose de luto, ou reflexãosobre os danos causados no agredido, é apenaso pensamento frio de uma racionalização daquilo que possa ser 
menos dispendioso a sua condição de culpado; culpado apenas pela sanção da lei e não por sentimento próprio e elaborado via autonomia crítica.

[...] que as ovelhas tenham rancor às grandes aves de rapina não surpreende: mas não é motivo para censurar às aves de rapina o fato de pegarem as ovelhinhas. $\mathrm{E}$ se as ovelhas dizem entre si: "essas aves de rapina são más; e quem for o menos possível ave de rapina, e sim o seu oposto, ovelha- este não deveria ser bom?", não há o que objetar a esse modo de erigir um ideal, exceto talvez que as aves de rapina assistirão a isso com ar zombeteiro, e dirão para si mesmas: "nós as amamos: nada mais delicioso do que uma tenra ovelhinha" (NIETZSCHE, 1998, p.35-36).

Para Nietzsche as consequências àquele que fora destituído do acesso à cultura tem como reverso defensivo maltratar a dimensão daquilo que não pôde adentrar. Assim, elimina-se os vestígios daquilo que o permite reconhecer suas dificuldades perante suas tentativas desiguais de ajustamento sociocultural, lembrete de suas frustrações e fracassos. Por isso destila cólera a objetos sem a sua identificação e objetifica pessoas que tragam semelhança. Adorno (2008) em suas reflexões a partir da vida lesada, diz que o sujeito com condições econômicas que se dedica a fazer arte ou trabalho intelectual, encontra certa dureza. Pela inveja de sua independência, e por desconfiarem da seriedade de seu trabalho. Essa desconfiança, revela ressentimento e também fundamento. Entretanto, a verdadeira resistência não é a desconfiança; é tornar a ocupação do espírito em algo prático, empreendedor, divisão de trabalho rigorosa com ramos específicos e restrições à entrada. Esse sujeito não é visto como profissional por mais aprimorado que o seja, todavia como o amador que flerta com o objeto de um profissional e para fazer carreira é preciso se diluir, se limitar. Quem abandona a divisão de trabalho por puro prazer no que faz, torna-se tanto mais vulnerável aos critérios dela, mesmo sendo superior a ela. Ressentimento, menosprezo à cultura e ao que se reporta à civilidade destacama vida danificada.

Nesse propósito, Adorno e Horkheimer (1985),na esteira do Nietzsche, elucidaram situações degenerativas à constituição do sujeito:a educação pela dureza. Em termos genéricos é a 
capacidade de suportar a dor e reprimir medos (ADORNO, 1995a). Suas bases têm a gênese no processo material em cujas forças agressivas de produção objetiva exigem e impõem medos de variadas ordens nos sujeitos, só que, ao mesmo tempo, proíbem-lhes de demonstrá-los.Na escola, o aluno faz a introversão de sacrifícios em decorrência de conflitos com outros alunos e professores num espaço socialmente repressivo.E o sujeito que reprime medos e é duro contra si numa relação de domínio sem trégua, recebe como resultado de sua coisificação o falso direito de imputar com maior rigor e severidade, dores no outro. $\mathrm{O}$ efeito é expelido na manufatura de matéria-prima do ódio, na dureza do controle de si, numa educação invertida de seu imperativo primordial, é adaptativa e não diretiva à autonomia, palco de vingança e ressentimento.A inibição brutal à criança pode trazer ganho de experiência, mas dureza e deformação, o suficiente para tornar as pessoas burras, impotentes e estagnadas na maldade, teimosia e fanatismo(ADORNO e HORKHEIMER, 1985). Como posto,Nietzsche (1998) fala do condicionamento do sujeito reativo defensivamentemediante o objeto exterior que se oferece a sua experienciação, a sua direção interna, tem-se o sujeito encalacrado emmônadas. Já Adorno e Horkheimer (1985) nos diz da questão da detração e mutilamento dos princípios da reflexão e ainibição de utopias em consequência da experiência traumática, o que reverbera na sedimentação de pontos cegos no íntimo do sujeito cuja agressividade será o melhor a oferecer.

Todo sacrifício é uma restauração desmentida pela realidade histórica na qual ela é empreendida. A fé venerável no sacrifício, porém, já é provavelmente um esquema inculcado, segundo o qual os indivíduos subjugados infligem mais uma vez a si próprios a injustiça que lhes foi infligida, a fim de poder suportála. (ADORNO e HORKHEIMER, 1985, p. 52).

O ressentido introverte o sacrificio e a dureza, e ao se ludibriar que extrai gozo retroalimentao rancor, já que " quem pratica a renúncia dá mais de sua vida do que lhe é restituído, mais do que a vida que ele defende"(ADORNO e HORKHEIMER, 1985, p.54). No entanto, para melhor alcance de reflexão é interessante mostrar, de chofre, o esclarecimento dialético proposto pelos frankfurtianos. Adorno e Horkheimer (1985) inauguraram o repaginamento da angústia mítica do

Problemata: R. Intern. Fil. v.6, n. 3(2015), p 378-403 ISSN 2236-8612 
Homem, ao evidenciar a cisão entre sujeito e objeto: o domínio da natureza externa e interna, ambas ameaçadoras.

$\mathrm{Na}$ efetivação de suas complexas análises resulta o duplo estendimento: rememorar a gênese psicológica, por um lado, e a gênese das questões sociais, por outro.De posse disso, o alongamento da reflexão remonta aos primórdios da humanidade na proto-história na qual o mito era esclarecimento e este repousavana concretude da mitificação. Essa forma rudimentar de elaboração do pensamento para mitigar o medo deparado com a prepotência descomunal da natureza desembrulha a lógica invertida da racionalidade: o operacionalismo sistematizado e calculado para designar as formas, teorizar e fecundar a abstração da própria natureza de forma não espontânea e livre, notificou que a gênese dessa razão ou o seu propósito excelso tinha em sua profundidade original, a emoção, amainar a tensão do pavor diante do desconhecido ameaçador, radicalizá-lo, portanto. $\mathrm{O}$ processo de desmitologização da sociedade em consonância ao domínio da ordem natural engruvinhado na radicalização da angústia mítica, recapitula uma racionalidade instrumental que matematiza o cálculo da precisão do espaço e tempo. O esclarecimento em si foi o processo sistemático de desencantamento.O primitivo ao obter em aparência o suposto domínio da natureza reverbera o fascínio a si enquanto Senhor, simultaneamente, em que ele próprio é parte do natural, é, pois natureza também, éescravo de seus domínios e tentativas de controle.

A forma da razão eram os mitos, depois a metafísica até a ciência positivista. Ocurso histórico social da dominação e controle se remodela às primitivas e toscas formas de esclarecimento a cada época. O primitivo se via obrigado a dominar-se e somente é possível com a dominação interna. Seu sentimento originário era o medo por conta da desproteção e desconhecimento. O delirium tremens ante o pavor descomedido da prepotência ameaçadora da natureza escancarou a dificuldade para se esconder a fragilidade e fraqueza de si que era, talvez, uma ameaça maior porque imaginariamente fortaleceria a ameaça externa.Quando o sentimento do medo está dentro, a solução é extroverter, desmaterializar. A criação dos mitos com imagens antropomórficas era a via comunicativa e projetiva do medo necessário ao ritual, oferece-se o objeto para receber algo, dinâmica sacrificial,trata-se de um movimento que celebra a 
renúncia, uma marca historicizada, um retorno ao fundamento, já que a história da civilização é a da introversão do sacrifício como denominam Adorno e Horkheimer (1985). A primitividade moderna dos rituais sadomasoquistas esportivos anuncia, no círculo do feiticeiro,a norma e a chancela de ferir, machucar para espetacularizar a cena de dominação de um pelo outro na qual ambos objetivam se autodominar. Ao vencer o oponente o lutador esmurra o peito como gesto arcaico de domínio de si, de sua própria natureza, superar a fraqueza ao expor a do outro é o mecanismo sacrificial de trocasde grande êxito efetuado na sociedade de mercado. É o alienar-se da natureza ao se abandonar nela tal como Ulisses que reconhece sua fraqueza a calculando e medindo-se para enfrentar os perigos. O recurso para ser vencedor é perder-se ganhando, espoliar-se de sua substância viva (ADORNO e HORKHEIMER, 1985). O fraco lembra a natureza que tem que ser contida ou destruída e para isso o impulso vocifera com revide e intensidades maiores. $\mathrm{O}$ medo de ser agredido desperta o desejo de ataque sem fim. A sociedade voltada à propulsão do capital produz indivíduos transmutados em guerreiros que precisam de magia para sobreviver, big brotherizados pelo lado de fora só resta o intento de escape ao encontro do perigo ameaçador.

\section{Considerações finais}

A que responde o consumodos esportes de combate e qual o sentido imputado pelos adeptos? Algumas sinalizações podem ser pensadas no plano material e psicológico: a dialética crítica de que o terror e a violência a que estamos sujeitos são melhores assimilados ou representados sob a estética espetacular a qual cumpriria a função elaborativa do sonho traumático, sendo, então, ressignificações de medo, doses de autovacina, para se encarar terrores maiores do cotidiano ao simular o trauma em catarses destrutivas. Em outro ponto,alternativas de fuga para frente ante o terror da exclusão e da meritocracia, ao fundo disso, legitimar o horror de uma vida dura ao obter a autorização para agredir com regras e lugar apropriado o endereçado imaginário da fúria. Para além, desnuda com crueza o vértice da violência mercadológica adquirida como sinonímia de liberdade e espectro de potência. Por efeito, isso explique que nas 
motivações psicológicas reside o ideal de provocar medo no outro, corpos agigantados gritam o poder de desarme a desafiadores ou provocadores imaginários. O inverso é válido aos corpos anoréxicos que são tentativas de ocultação de si, sumir com o próprio corpo ou perder-se dele para a sociedade não vê-lo e não ameaçá-lo.A adesão a atividades sadomasoquistasforja a sensação de que força, erotismo e saúde são transubstanciados aos integrados. Logo,não se trata de excesso de narcisismo, mas ausência de investimento simbólico para gerá-lo. Daí o porquê de sacrificar e modificar o corpo com agulhas, metais e quilos de músculos não só para adulterar resistência e coragem numa sociedade ultracompetitiva,todavia para sustentar egos miniaturizados e fragilizados. Na inverdade da astúcia, a fraude no sacrifício torna-se um elemento de caráter, uma mutilação do herói astuto arrojado pelo mar e cuja fisionomia está marcada pelos golpes que desferiu contra si para se autoconservar (ADORNO e HORKHEIMER, 1985).

Apesar disso, é preciso algumas ressalvas. Primeiro que faz parte das civilizações organizarem uma miríade de modalidades, tanto esportiva quanto sacrificial, talvez, estejam no mesmo plano de ação e retribuição, visto que se trata de distribuição de gozo, simulacros de pertencimento ritualísticos comungado entre os participantes tanto pelo lúdico quanto pelo sagrado para mitigar medos. Portanto, a intenção não é de criminalizar o objeto e sua historicidade. Segundo que a crítica é sobre a apropriação dos rituais pela indústria os tornando mais traumáticos e legitimadores da frieza e horror dos meios de produção adaptativos, com o intuito de formatação de humanos máquinas para atender as demandas industriais com claros prejuízos à formação. Mas o dilema persiste, para Adorno (1995a) é preciso se opor aos Folk-Ways, ritos de iniciação que infligem dor física insuportável como preço do direito de filiação da mesma ação no porvir. E à ciência cabe inverter essa tendência para refrear a brutalidade e fantasmagoria dos divertimentos populares.

Diante disso cabe a questão: numa sociedade regulada pela troca, inclusive do corpo, produtora de dores e que como camisa de força administra anestésicos excitativos em ritos sadomasoquistas, qual o movimento a educação cujas bases materiais históricas estão diluídas e desvanecidas de liberdade e crítica, pode, para se desviar dos constructos sociais da barbárie? 
Se o sistema educacional proporcionar que os indivíduos consigam ao menos falar e numa abstração maior, possam projetar seus ressentimentos e desejos de destruição na conversão de resistências à barbárie pela produção artística e intelectual e permutar a violência concreta pela via subjetiva simbólica, talvez fosse um indício a se refletir para mitigar a dominação social que limita a criatividade e confisca a fantasia ao desviar nossas energias ao autoconfronto destrutivo. Finalmente, elaborar o passado com política de crítica do esquecimento que repercuta nos sujeitos o imperativo de reconhecer os processos constitutivos de violência material na qual estão impingidos, é crível a psicólogos, professores e educadores que queiram restringir os determinantes contrapostos às necessidades sociais de uma existência mais humana.

\section{Referências}

ADORNO, Theodor; HORKHEIMER, Max. Dialética do Esclarecimento: fragmentos filosóficos. Tradução: Guido Antônio de Almeida. Rio de Janeiro: Jorge Zahar Editora, 1985. .Educação e Emancipação.Tradução: Wolfgang Leo Maar. Rio de Janeiro: Paz e Terra,1995a.

MinimaMoralia: reflexões a partir da vida lesada. Tradução: Gabriel Cohn. Rio de Janeiro: Beco do Azougue, 2008.

- Tempo livre. In: ADORNO, Theodor. Palavras e Sinais - Modelos Críticos 2. Tradução: Maria Helena Ruschel. Petrópolis: Editora Vozes, 1995b.

BENJAMIN, Walter. Documentos de cultura, documentos de barbárie:escritos escolhidos. Tradução: Celeste H. M. Ribeiro de Sousa. São Paulo: Cultrix: editora da Universidade de São Paulo, 1986.

Obras escolhidas. Vol. 1. Magia e técnica, arte e política. Tradução: Sérgio Paulo Rouanet. São Paulo: Brasiliense, 1994.

DEBORD, Guy. A sociedade do espetáculo. Tradução: Estela dos Santos Abreu. Rio de Janeiro: Contraponto, 2004.

GRUSCHKA, Andreas. Frieza burguesa e educação: a frieza como mal-estar moral da cultura burguesa na educação. 
Tradução: Gonçalves, Vilela, Strunk\&Zuin. Campinas-SP. Autores associados, 2014.

HARVEY, D. Condição pós-moderna.Tradução: Adail Ubirajara Sobral; Maria Stela Gonçalves: São Paulo. Edições Loyola. 2000.

KEPPLE, Anne W \& colaboradores. O estado da segurança alimentar e nutricional no Brasil: um retrato multidimensional.Relatório 2014. Brasília: 2014.90 p. Disponível

em: $<$ https://www.fao.org.br/download/SOFI_p.pdf.>. Acesso em: 15 mai. 2015.

NIETZSCHE, Friedrich. Genealogia da Moral: uma polêmica. Tradução: Paulo César de Souza. São Paulo: companhia das letras, 1998.

TÜRCKE, Christoph. Filosofia do sonho. Tradução: Paulo Rudi Schneider. Ijuí: Ed. Unijuí, 2010.

ZUIN, Antônio A.S. Indústria Cultural e Semiformação: a Atualidade da Educação após Auschwitz. Educação e Filosofia (UFU. Impresso), v. 25, p. 607-634, 2011. 